九州大学学術情報リポジトリ

Kyushu University Institutional Repository

\title{
Finding the Relationships between a Strain of Bacillus thuringiensis, Tannic Acid, and the Mid-gut Proteases of Spodoptera exigua
}

Jin, Na Young

Department of Applied Biology, College of Agriculture and Life Sciences, Chungnam National University

Lee, You Kyoung

Department of Biosystems Machinery Engineering, College of Agriculture and Life Sciences, Chungnam National University,

\section{Lee, Bo Ram}

Department of Applied Biology, College of Agriculture and Life Sciences, Chungnam National University

\section{Kim, Yu Seop}

Department of Applied Biology, College of Agriculture and Life Sciences, Chungnam National University

他

https://doi.org/10.5109/1685888

出版情報：九州大学大学院農学研究院紀要. 61 (2)，pp.319-329，2016-09-01. Faculty of Agriculture, Kyushu University

バージョン :

権利関係 : 


\title{
Finding the Relationships between a Strain of Bacillus thuringiensis, Tannic Acid, and the Mid-gut Proteases of Spodoptera exigua
}

\author{
Na Young JIN ${ }^{1}$, You Kyoung LEE ${ }^{1}$, Bo Ram LEE ${ }^{1}$, Yu Seop KIM'1, \\ Jun Hack JUN ${ }^{1}$, Hee Ji KIM ${ }^{1}$, Young Nam YOUN ${ }^{1}$, \\ Chisa YASUNAGA-AOKI*and Yong Man YU ${ }^{1 *}$
}

\author{
Laboratory of Insect Pathology and Microbial Control, Institute of Biological Control, \\ Faculty of Agriculture, Kyushu University, Fukuoka 812-8581, Japan \\ (Received April 28, 2016 and accepted May 10, 2016)
}

\begin{abstract}
A new strain of Bacillus thuringiensis exhibiting activity in Spodoptera exigua was isolated and identified. Synergistic effects appeared when it was mixed with tannic acid, which is a protease inhibitor that enhances insecticidal activities. Substrate reactions with different types of proteases were analyzed, and according to the results, trypsin showed proteolytic activity levels of $91.4 \%$ and $89.4 \%$ on BApNA and BPVApNA substrates, respectively. When trypsin was treated with tannic acid, proteolytic activity levels of $62.2 \%$ and $54.5 \%$ appeared on BApNA and BPVApNA substrates, respectively, and tannic acid suppressed the trypsin-substrate reactions by $29.2 \%$ and $34.9 \%$, respectively. Colorimetric activity assays of trypsin identified slightly lower activity levels in larvae that ate a combination of $B$. thuringiensis KB100 strain and 40 $\mathrm{mM}$ of tannic acid, when compared to larvae that died after eating the positive control, control, or the $B$. thuringiensis subsp. kurstaki KB100. The results of trypsin gene expression level analyses conducted using the qRT-PCR analyses indicated that trypsin 1 gene expression levels were lower when $40 \mathrm{mM}$ of tannic acid was added to the $B$. thuringiensis KB100 strain, compared to the B. thuringiensis KB100 strain alone. Trypsin 2 gene expression levels were also lower when $40 \mathrm{mM}$ of tannic acid was added to the $B$. thuringiensis KB100 strain. The results of immunofluorescence antibody experiments indicated that the addition of $40 \mathrm{mM}$ of tannic acid to the B. thuringiensis KB100 strain, during decomposition by the mid-gut proteases of $S$. exigua, led to differences in expression levels and image analyses.
\end{abstract}

Key words: Bacillus thuringiensis, Protease, Protease inhibitor, Spodoptera exigua, Synergistic effect, Tannic acid, Trypsin

\section{INTRODUCTION}

Spodoptera exigua, which is a major, omnivorous agricultural pest, has not only been widely reported in tropical, subtropical, and temperate regions (Mochida and Okada, 1974), but also shown to be harmful to a variety of plants, including vegetables, flower plants, fruit trees, whole crops, and special purpose crops. There are 52 suitable host plants in South Korea (Goh et al., 1991), and S. exigua is known to harm approximately 140 species of plants globally (Minamikawa, 1937; Mochida and Okada, 1974).

Control methods for $S$. exigua include chemical controls consisting of insecticides such as organophosphorus, cabamate, and pyrethroid (Eveleens et al., 1973), biological controls using natural enemies, and attracticide and mating disruption using sex pheromones (Yoo et al., 1995; Jung et al., 2003; Kim et al., 2004). This pest cannot be easily controlled during its third instar period or thereafter because of high resistance to organic synthetic insecticides, which has developed from its ecological characteristics (Meinke and Ware, 1978). Therefore, biological control was introduced to control cases of resistant and intractable pests.

${ }^{1}$ Department of Applied Biology, College of Agriculture and Life Sciences, Chungnam National University, Daejon 305-764, Korea

* Joint corresponding authors (E-mail: ymyu@cnu.ac.kr and yasunaga@grt.kyushu-u.ac.jp)
Bacillus thuringiensis products are the most widely used in biological control. B. thuringiensis was first isolated in 1901 in Japan, from the bodies of infected silkworm larvae. It forms spores and protein (parasporal) crystals in its rod-shaped cells. B. thuringiensis' insecticidal crystal proteins appear in diverse forms, such as bipyramidal, spherical, and indeterminate forms. In general, the bipyramid type one form exhibits highly toxic activity on Lepidoptera larvae (Jin et al., 2009). Cry proteins that are toxins with insecticidal activities include 149 cry proteins (Cry1-Cry51) and nine cyt proteins (Cyt1-Cyt2), which were isolated by Raymond et al. (2010).

Insecticidal crystalline proteins (ICPs) produced by B. thuringiensis do not exhibit any insecticidal activity. Specific insect mid-gut proteases are essential for the production of $B$. thuringiensis toxins (i.e., ICPs). $B$. thuringiensis is divided into $55-70 \mathrm{kDa}$ through proteolysis by mid-gut proteases. These toxins interact with the larvae's mid-gut epithelial cells to form holes in the cell membranes, eventually leading to the death of the larvae. ICPs, which are endotoxin proteins in B. thuringiensis, are decomposed by strong alkaline digestive enzymes generated in the mid-gut of susceptible insects.

Lepidoptera's proteinases are divided into three groups: (i) serine proteinases, (ii) cysteine proteinases, and (iii) aspartic proteinases. S. exigua's proteases are known to be serine proteinases and cysteine proteinases (Jongsma et al., 1996). Proteases are the most important digestive enzymes for $B$. thuringiensis' activity. Trypsin 
and chymotrypsin, which are serine proteinases, are known to play major roles in the process of proteolysis (Tojo and Aizawa, 1983; Zhu et al., 2007) and are the most important digestive enzymes for activation of $B$. thuringiensis' protoxins in insect mid-guts, which are important for the decomposition of ICPs (Zhu et al., 2007; Oppert, 1999). In particular, trypsin is known to decompose cry 1 proteins that are highly active in $S$. exigua (Rukmini et al., 2000); however, mid-gut proteases may lead to toxin protein inactivation through continuous hydrolysis.

These changes in mid-gut proteases and activity may lead to resistance and tolerance to $B$. thuringiensis. Forcada et al. (1996) reported that Heliothis virescens' mid-gut fluid is resistant to $B$. thuringiensis and decomposes $B$. thuringiensis toxins in vitro faster than susceptible mid-gut fluids are able to. Furthermore, it has been reported that in the case of highly tolerant pests, such as $S$. exigua, B. thuringiensis is excessively decomposed by mid-gut proteases, leading to reduced insecticidal activities (Maclntosh et al., 1990). Excessive decomposition of $B$. thuringiensis protoxins by mid-gut fluids containing trypsin-, chymotrypsin-, and elastaselike breakdown enzymes in $H$. armigera larvae demonstrate this resistance (Zhu et al., 2007).

In previous studies, $B$. thuringiensis, which is highly active in $S$. exigua, and tannic acid were selected as protease inhibitors, which prevent excessive decomposition of $B$. thuringiensis' toxin proteins due to the strong digestive activity of the pests' mid-gut fluids. The fact that $B$. thuringiensis showed high activity when tannic acid was added to it was identified (Jin et al., 2009, 2015). In addition, the secondary metabolites of plants are protease inhibitors that play important roles in pest resistance. It is known that in cotton, many secondary metabolites, such as terpenes, flavones, and tannis, act on pests as feeding deterrents, anthelminthics, growth inhibitors, and toxins (Rhoades and Cates, 1976). Tannins inhibit or weaken the growth of larvae and pupae (Chan et al., 1978) and have been reported to reduce larval feeding and enhance the effects of $B$. thuringiensis (Lord and Undeen, 1990; Navon et al., 1993). According to a report by Salama et al. (1984), tannic acid increased the efficacy of $\delta$-endotoxin by two to four times, and after eating tannic acid, the $\mathrm{pH}$ in insect mid-guts rose, increasing the effects of $B$. thuringiensis (Schnepf et al., 1998). However, the mechanism of interaction between $B$. thuringiensis and tannic acid has not yet been identified.

In the present study, attempts were made to find the cause of the synergistic effects that appear when $B$. thuringiensis and tannic acid are mixed. Since the acting mechanism of tannic acid as a protease inhibitor has not been identified, experiments were conducting focusing on the determination of the relationship between tannic acid and proteases.

\section{MATERIALS AND METHODS}

\section{Experimental insects}

The Plutela xylostella used in the present experi- ment were collected from an outdoor population and successively bred in the insect breeding room in the biological pest control laboratory of Chungnam National University, using Chinese cabbage as a feed. Spodoptera litura and $S$. exigua were purchased from the National Institute of Agricultural Science and Technology of the Rural Development Administration and used while being successively bred with artificial feeds (Goh et al., 1990). As a feed for imagoes, 10\% sugar water was supplied to the spawning box (plastic, diameter: $20 \mathrm{~cm}$, height; $15 \mathrm{~cm}$ ). All the insects were bred under the same breeding conditions as follows: temperature $25 \pm^{\circ} \mathrm{C}$, lighting condition $16 \mathrm{~L}: 8 \mathrm{D}$, and relative humidity 50-60\%.

\section{Plasmid DNA extraction}

The plasmid DNA of the B. thuringiensis strain was extracted using a Qiagen midi kit to identify the plasmid DNA. First, $10 \mathrm{ml}$ of $B$. thuringiensis was inoculated into luria-bertani (LB) media and cultured for 16 hours at $28^{\circ} \mathrm{C}$ and centrifuged at $200 \mathrm{rpm}$. Thereafter, $1 \mathrm{ml}$ of the culture fluid was inoculated into $100 \mathrm{ml}$ of a SPY medium $\left(0.2 \%\left(\mathrm{NH}_{4}\right)_{2} \mathrm{PO}_{4} ; 1.4 \% \mathrm{~K}_{2} \mathrm{HPO}_{4} ; 0.6 \% \mathrm{KH}_{2} \mathrm{PO}_{4}\right.$; $0.1 \%$ sodium citrate; $0.02 \% \mathrm{MgSO}_{4} \cdot 7 \mathrm{H}_{2} \mathrm{O}, 0.1 \%$ yeast extract; and $0.1 \%$ glucose) to culture the bacteria for approximately four hours until the measured value of $\mathrm{OD}_{600}$ became 0.7-1.0. All the cultured bacteria were subjected to centrifugation at 10,000 rpm for 5 minutes at $4^{\circ} \mathrm{C}$. Thereafter, the supernatant was discarded and only the microbial cells were collected. Then, $4 \mathrm{ml}$ of P1 solution $(50 \mathrm{mM}$ tris $\cdot \mathrm{Cl}$, pH8; $10 \mathrm{mM}$ EDTA; and $100 \mu \mathrm{g} / \mathrm{ml}$ RNaseA) and $50 \mu \mathrm{l}$ of lysozyme $(50 \mathrm{mg} / \mathrm{ml})$ were added to the microbial cells, and the mixture was kept at $37^{\circ} \mathrm{C}$ for approximately 30 minutes to induce reactions. Thereafter, $4 \mathrm{ml}$ of the P2 solution (200 mM NaOH, 1\% SDS) was added to the mixture, and reactions were induced in ICE for approximately 15 minutes. The mixture was then subjected to centrifugation at 12,000 rpm for 5 minutes at $4^{\circ} \mathrm{C}$. The supernatant fluid was moved to a new tube and subjected to centrifugation at $15,000 \mathrm{rpm}$ for 30 minutes at $4^{\circ} \mathrm{C}$. A Qiagen-tip 100 was installed on the tube, and $4 \mathrm{ml}$ of QBT solution $(750 \mathrm{mM}$ $\mathrm{NaCl}$; $50 \mathrm{mM}$ MOPS; 15\% isopropanol; and 0.15\% Triton) was added, followed by $5 \mathrm{ml}$ of a QC buffer $(1 \mathrm{M} \mathrm{NaCl}$; $50 \mathrm{ml}$ MOPS; and 15\% isopropanol). The tube below the Qiagen-tip 100 was replaced and $5 \mathrm{ml}$ of a $\mathrm{QF}$ buffer (1.25 M NaCl; $50 \mathrm{mM}$ Tris . Cl; and 15\% isopropanol) was added. Then, $1 \mathrm{ml}$ of each fluid gathered in the tube was placed in a $2 \mathrm{ml}$ Eppendorf tube, and $0.7 \mathrm{ml}$ of isopropyl alcohol (IPA) was added. The solution was subjected to centrifugation at $13,000 \mathrm{rpm}$ for 30 minutes at $4^{\circ} \mathrm{C}$. The supernatant fluid was discarded, $70 \%$ alcohol was added to the tube, and the solution was subjected to centrifugation again. Then, the fluid was discarded and the Eppendorf tube was placed on a clean bench until moisture in the tube disappeared. After drying, $10 \mu \mathrm{l}$ of sterilized water was placed in the tube to dissolve any residue, the solution was subject to electrophoresis in $0.7 \%$ agarose gel for 60 minutes at $50 \mathrm{~V}$, and the results were checked. 


\section{PCR analysis}

Gene-specific primer sets (Table 1) were used to identify cry-type genes among the endotoxin genes of $B$. thuringiensis. A Thermal Cycle C1000TM (BIO-RAD) was used for PCR amplification. The final volume of the sample used in the analysis was $20 \mu \mathrm{l}$ and created by mixing the premix (Bioneer) containing buffer solution components and dNTP with the template DNA $(1.0 \mu \mathrm{l})$, the primer sets $(1.0 \mu \mathrm{l}$ each), and distilled water $(17 \mu \mathrm{l})$. PCR was implemented for 30 cycles at $95^{\circ} \mathrm{C}$ and 5 minutes, $94^{\circ} \mathrm{C}$ and 1 minute, $57^{\circ} \mathrm{C}$ and 1 minute, $72^{\circ} \mathrm{C}$ and 1 minute, and $72^{\circ} \mathrm{C}$ and 5 minutes to produce PCR products. Cry genes were identified through electrophoresis in 1.2\% agarose gel (Yang et al., 2011; Abdullah et al., 2009; Ye et al., 2009).

\section{Western blotting analysis}

Western blotting analysis was conducted using the methods presented by Xue et al. (2008) and Isabel et al. (2014), with some modifications. A nitrocellulose membrane was sufficiently wetted with a blotting buffer (25 mM Tris, pH 8.3; $192 \mathrm{mM}$ glycine; and 20\% v/v methanol) for 10 minutes. The gel that underwent SDS-PAGE was blotted to the membrane for two hours at $70 \mathrm{~V}$ using a blotting tank. After the blotting, the membrane was immersed in a 5\% skimmed milk solution diluted with a TBS-T buffer and stirred for one hour at room temperature. After the initial stirring, the membrane was stirred in a wash buffer (TBS-T buffer) three times for five minutes each time. The primary antibody [anti-Bacillus thuringiensis cry1 Ab toxin antibody (Ca.ab51586)] was diluted to a ratio of 1:1000 with the TBS-T buffer, the membrane was immersed in the solution, and the solution was stirred for three hours at room temperature. The membrane was immersed in a new wash buffer, which was stirred three times for five minutes each time. The secondary antibody [goat anti-rabbit IgG (HL)-HRP conjugate (Ca.170-6515)] was diluted to a ratio of 1:10,000 with a TBS-T buffer, the membrane was immersed in the solution, and the solution was stirred for one hour at room temperature. Again, the membrane was immersed in a new wash buffer, and the wash buffer was stirred three times for five minutes each time. Films were developed from the membrane using the chemiluminescence detection method and X-ray films.

\section{Measurement of protease activities in S. exigua}

To measure protease activities, experiments were conducted using the method presented by Bradford (1976), with some modification. To measure the activities of individual digestive enzymes, $\mathrm{N} \alpha$-Benzoyl-DL-arginine 4-nitroanilide hydrochloride (BApNA) and N-BenzoylPhe-Val-Arg-p-nitroanilide hydrochlorid (BPVApNA) were used as trypsin protease substrates; N-Benzoyl-Ltyrosine p-nitroanilide (BTpNA), N-Succinyl- Ala-AlaPro-Phe p-nitroanilide (SAAPPpNA), and Ala-Ala-ValAla p-nitroanilide (AAVApNA) were used as chymotrypsin protease substrates; and N-Succinyl-Ala-Ala-Alap-nitroanilide (SAAApNA) and N-Succinyl-Ala-AlaPro-Leu p-nitroanilide (SAAPLpNA) were used as elastase protease substrates. To identify the inhibitory activity of tannic acid on the mid-gut fluid of S. exigua, an azocasein substrate was used at different concentrations $(10,20,40$, and $80 \mathrm{mM})$ during analyes. S. exigua's mid-gut fluid diluted with distilled water and tannic acid were mixed to a ratio of $1: 1$ and kept at $37^{\circ} \mathrm{C}$ for 15 minutes to induce reactions. After mixing $300 \mu \mathrm{l}$ of each substrate with $100 \mu \mathrm{l}$ of a digested sample, the mixture was kept at $37^{\circ} \mathrm{C}$ for 15 minutes to induce reactions. Thereafter, $200 \mu \mathrm{l}$ of $10 \%$ TCA was added to the mixture to stop the reactions. After subjecting the sample to centrifugation for 30 minutes at $15,000 \mathrm{rpm}$ and $4^{\circ} \mathrm{C}$, the supernatant fluid was mixed with $1 \mathrm{M}$ of $\mathrm{NaOH}$ to a ratio of $1: 1$ to condense proteins, and the protein concentration was measured at an optical density of $405 \mathrm{~nm}$ (Jin et al., 2015).

Table 1. Crystal protein gene-specific primers for PCR analysis

\begin{tabular}{clc}
\hline Cry genes & \multicolumn{1}{c}{ Primer sequences } & Size of product (bp) \\
\hline cry1Aa & 5'GAGCCAAGCGACTGGAGCAGTTTACACC3' & 782 \\
cry1Ab & 5'TCGAATTGAATTTGTTCC3' & 238 \\
cry1Ac & 5'GTCCAACCTTATGAGTCACCTGGGCTTC3' & 550 \\
cry1B & 5'GTCCAACCTTATGAGTCACCTGGGCTTC3' & 902 \\
cry1C & 5'CAACCCTATTTGGTGCAGGTTC3' & 288 \\
cry1D & 5'GGTACATTTAGATGTTCACAGCCAC3' & 465 \\
cry1E & 5'CTTAGGGATAAATGTAAGTACAG3' & 961 \\
cry1F & 5'CCGGTGACCCATTAACATTCCAATC3' & 383 \\
cry13' & 5'ATCACTGAGTCGCTTCGCATCTTTGACTTTCTC3' & - \\
cry1G5' & 5'ATATGGAGTGAATAGGGGG3' & 235 \\
cry1G3' & 5'TGAACGGCGATTACATGC3' & - \\
cry115' & 5'GCTGTCTACCATGATTCGCTTG3' & 1584 \\
cry113' & 5'CAGTGCAGTAACCTTCTCTTGC3' & - \\
\hline
\end{tabular}




\section{Trypsin activity analysis}

The activity of trypsin among $S$. exigua mid-gut proteases was analyzed using a trypsin activity colorimetric assay kit (Biovision, catalog \#K771-100). Live S. exigua, those larvae that died after eating the $B$. thuringiensis KB100 strain, and those larvae (10-100 mg) that died after eating the $B$. thuringiensis KB100 strain and $40 \mathrm{mM}$ tannic acid were cut to small pieces, and a trypsin assay buffer was added at $4 \mathrm{X}-6 \mathrm{X}$ volumes. The solutions were kept on ice. While observing the cells under a microscope, the lyses were completed and the solutions were homogenized using a homogenizer (10-15 repetitions), while iced. After the samples were subjected to centrifugation, only the supernatant fluids were collected and inoculated into 96-plate wells. When the final volume was smaller than $50 \mu \mathrm{l}$, an equal amount of assay buffer was added $(50 \mu \mathrm{l})$. Each sample was treated with $1 \mu \mathrm{l}$ of a chymotrypsin inhibitor (TPCK) solution and kept at room temperature for 10 minutes to induce reactions. To prepare a positive control, a trypsin buffer $(45 \mu \mathrm{l})$ and a positive control solution $(5 \mu \mathrm{l})$ were mixed together and $2 \mathrm{mM}$ of a p-NA standard in a micro-centrifuge tube were used to prepare a standard curve. The standard diluted solution $(50 \mu \mathrm{l})$ was added to each 96-plate well to produce a sufficient quantity of the $2 \times$ duplicates $\times 50 \mu \mathrm{l} /$ well. Then, $50 \mu \mathrm{l}$ of the reaction mixture was prepared for each well by mixing the assay buffer $(48 \mu \mathrm{l})$ and trypsin substrate $(2 \mu \mathrm{l})$. Each well that contained p-NA standards, positive controls, test samples, or the trypsin inhibitor control was added to the $50 \mu \mathrm{l}$ of the reaction mixture. The solutions were cultured for one to two hours (or longer when trypsin activity was low) at $25^{\circ} \mathrm{C}$, and protein concentrations were measured at an optical density of $405 \mathrm{~nm}$ using a microplate reader system (VersaMax).

\section{S. exigua's total RNA extraction and cDNA syn- thesis}

Total RNAs were extracted from untreated larvae, those larvae that died after eating the $B$. thuringiensis KB100 strain, and those larvae that died after eating the B. thuringiensis KB100 strain and $40 \mathrm{mM}$ of tannic acid, using Qiagen RNeasy mini kits (Qiagen, Korea) pursuant to the protocol. Then, cDNAs were synthesized using LA TaqTM DNA polymerase (Takara, Japan).

RNase-free $\mathrm{H} 2 \mathrm{O}(7 \mu \mathrm{l}), 5 \times \mathrm{RT}$ buffer $(4 \mu \mathrm{l})$, dNTP $(2 \mu \mathrm{l})$, RNase inhibitor $(1 \mu \mathrm{l})$, primer (forward: 5' TCCACCTGGGCCAACAGC 3', reverse: 5' ACGATGCCGTTGTGGTAGAG 3'; $0.5 \mu \mathrm{l})$, RNA (4 $\mu \mathrm{l})$, and Revertra Ace $(1 \mu \mathrm{l})$ were mixed together and treated at $42^{\circ} \mathrm{C}$ for 20 minutes and at $99^{\circ} \mathrm{C}$ for five minutes to synthesize the second strand. Primers were made using the trypsin RNA sequences for four Lepidoptera species (S. litura, Heliothis armigera, $H$. virescens, and Spodoptera frugiperda) because the trypsin RNA sequence for $S$. exigua was not registered in the

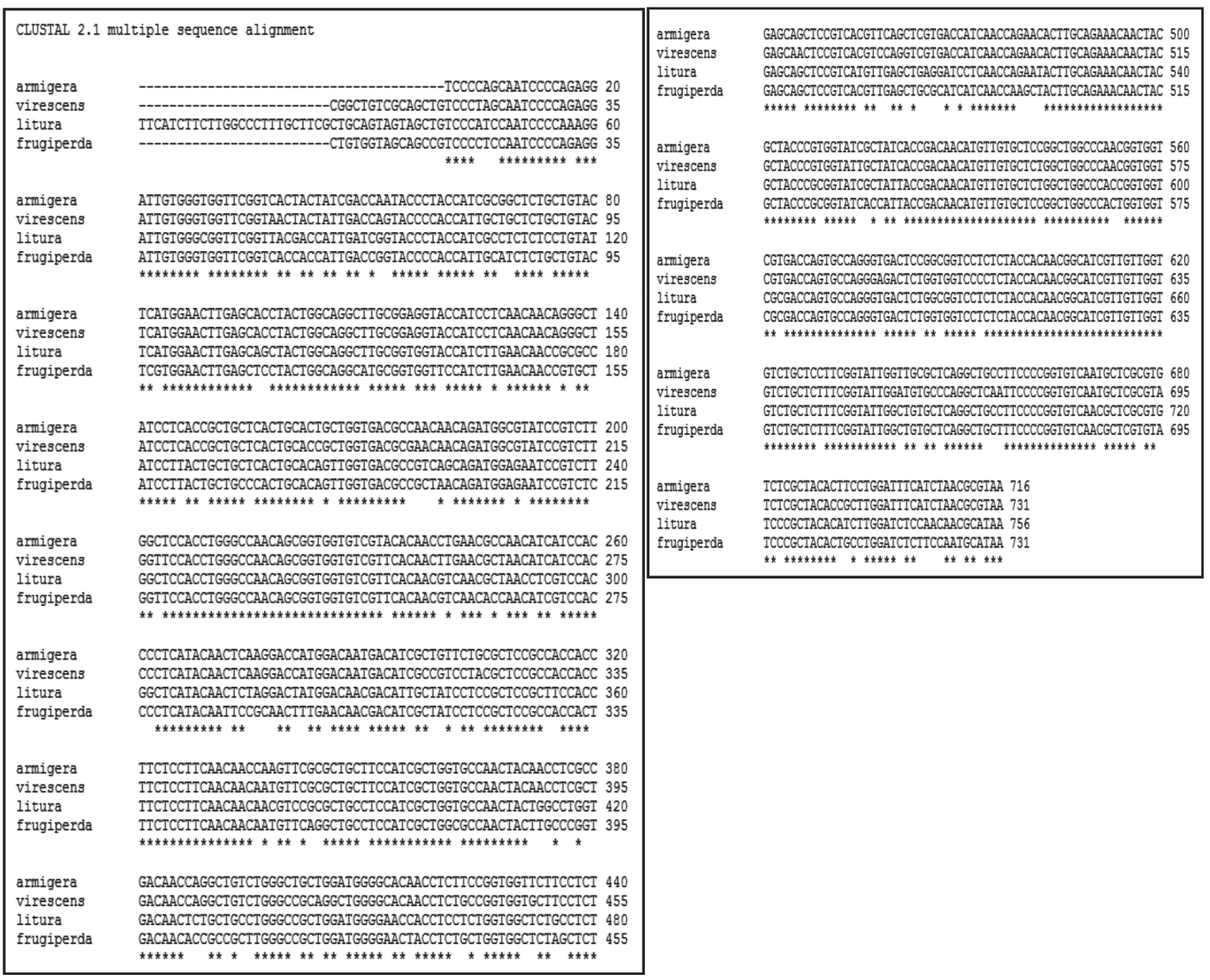

Fig. 1. S. exigua trypsin using a trypsin mRNA sequence analysis of the few species of lepidoptera in Genbank (primer production). 
Table 2. Oligonucleotide primers for qRT-PCR

\begin{tabular}{|c|c|c|c|c|}
\hline Gene & Primer sequences & Length & Position & $\begin{array}{c}\text { PCR product } \\
\text { (bp) }\end{array}$ \\
\hline Trypsin 1 & Sense: ACGACATCGCTATCCTCC & 18 & 86 & 85 \\
\hline Trypsin 1 & Antisense: GAAGTAGTTGGAACCAGCAA & 20 & 171 & 85 \\
\hline Trypsin 2 & Sense: CATCGTTCACGGTTCATACA & 20 & 48 & 93 \\
\hline Trypsin 2 & Antisense: GCGGACATTGTTGTTGAAG & 19 & 141 & 93 \\
\hline Actin & Sense: ATCGTGCGTGACATCAAG & 18 & 687 & 110 \\
\hline Actin & Antisense: GTCGGGAAGTTCGTAGGA & 18 & 797 & 110 \\
\hline
\end{tabular}

Genbank. After checking with the Genbank, the primers were made assuming that $S$. exigua should also have a partially common trypsin RNA sequence (Fig. 1). Actin (forward: 5'CCCAGAGCAAGAGAGGTATC 3', reverse: 5'ACCCCTCTCGGTGAGGATCT 3') was used as a positive control. After synthesizing, cDNA was subjected to electrophoresis in $0.8 \%$ agarose gel at $60 \mathrm{~V}$ for 33 minutes.

\section{S. exigua trypsin gene sequencing and qRT-PCR analysis}

The qRT-PCR method presented by Kaminska et al. (2014) was used with some modification to analyze the expression level of trypsin genes among the mid-gut proteases of $S$. exigua. Primers for qRT-PCR were made to check the levels of expression of the trypsin genes and actin of $S$. exigua (Table 2). First, cDNA (5 $\mu$ l) of each of the untreated larvae, larvae that died after eating the $B$. thuringiensis KB100 strain, and larvae that died after eating the $B$. thuringiensis $\mathrm{KB} 100$ strain and $40 \mathrm{mM}$ of tannic acid were mixed with a $2 \times \operatorname{SYBR}$ mix $(10 \mu \mathrm{l})$, primer $(0.5 \mu \mathrm{l})$, and distilled water $(4 \mu \mathrm{l})$ in each 96 -plate well, and reactions were induced. The qRT-PCR condition was 32 cycles at $25^{\circ} \mathrm{C}$ for 10 minutes, $37^{\circ} \mathrm{C}$ for 12 minutes, $85^{\circ} \mathrm{C}$ for 5 minutes, and $4^{\circ} \mathrm{C}$ for 5 minutes. The trypsin gene expression level analysis was conducted using the method presented by Pfaffl (2001).

\section{S. exigua trypsin gene sequencing and qRT-PCR analysis}

The qRT-PCR method presented by Kaminska et al. (2014) was used with some modification to analyze the expression level of trypsin genes among the mid-gut proteases of $S$. exigua. Primers for qRT-PCR were made to check the levels of expression of the trypsin genes and actin of $S$. exigua (Table 2). First, cDNA ( $5 \mu \mathrm{l})$ of each of the untreated larvae, larvae that died after eating the B. thuringiensis KB100 strain, and larvae that died after eating the $B$. thuringiensis $\mathrm{KB} 100$ strain and $40 \mathrm{mM}$ of tannic acid were mixed with a $2 \times \operatorname{SYBR} \operatorname{mix}(10 \mu \mathrm{l})$, primer $(0.5 \mu \mathrm{l})$, and distilled water $(4 \mu \mathrm{l})$ in each $96-$ plate well, and reactions were induced. The qRT-PCR condition was 32 cycles at $25^{\circ} \mathrm{C}$ for 10 minutes, $37^{\circ} \mathrm{C}$ for 12 minutes, $85^{\circ} \mathrm{C}$ for 5 minutes, and $4^{\circ} \mathrm{C}$ for 5 minutes. The trypsin gene expression level analysis was conducted using the method presented by Pfaffl (2001).

\section{Immunofluorescence antibody method and confo- cal laser scanning microscopy}

Immunofluorescence experiments were conducted to identify the activity of trypsin in the body of $S$. exigua using the method presented by Ruiz et al. (2004), with some modification. A spore-crystal mixture solution $(50 \mu \mathrm{l})$ diluted with $40 \mathrm{mM}$ of tannic acid $(15 \mu \mathrm{l})$ was sprayed on $0.2 \mathrm{~g}$ of an artificial feed. The primary trypsin antibody (Santa Cruz Biotechnology, Cat.sc-137077) was diluted to 1:500 with sterilized water and the secondary mouse IgG2a antibody (Bethyl Laboratory, Cat. A90-107F) diluted to 1:100, before both were inoculated into the feed. Two third-instar larvae, starved for 12 hours, were put into each petri dish and allowed to eat feed for 30 minutes. After eating, each larva was put into each well of a 96-well black immunoplate, and the trypsin expression levels of the larvae were identified using an immunofluorescence microplate reader (Hidex Sense, Cat.425-301). After identifying the expression levels, images of trypsin expressed in the bodies of the pests were taken using a confocal laser scanning microscope (Leica, TCS SP8 STED).

\section{RESULTS AND DISCUSSION}

\section{Analysis of the cry genes of the $B$. thuringiensis subsp. kurstaki KB100}

The $B$. thuringiensis subsp. kurstaki HD-1 has been reported as having cry1Aa, cry1Ab, cry1Ac, and cry1I genes (Jung et al., 2010), and several B. thuringiensis subspecies, including aizawai and entomocidus, have been reported as having cry $1 \mathrm{Aa}$, cry1 Ab, cry1E, and cry $1 \mathrm{~F}$ genes and showing activity in Lepidoptera (Sanchis et al., 1989; Visser et al., 1988, 1990). Cry1 genes having insecticidal activities on $S$. exigua are assumed to include cry1Aa, cry1Ab, cry1C (de Maagd et al., 2003), cry1D (Bravo et al., 1998; Porcar et al., 2000; Lee et al., 2001), and cry1F (Luo et al., 1999; Hernández and Ferre, $2005)$ genes. In addition, cry1 genes have been reported as showing activity on Lepidoptera and Coleoptera (Tamez-Guerra et al., 2004), and cry2 genes have been reported as having activity on Lepidoptera and Diptera (Donovan et al., 1994).

According to the results of examination, the kurs- 


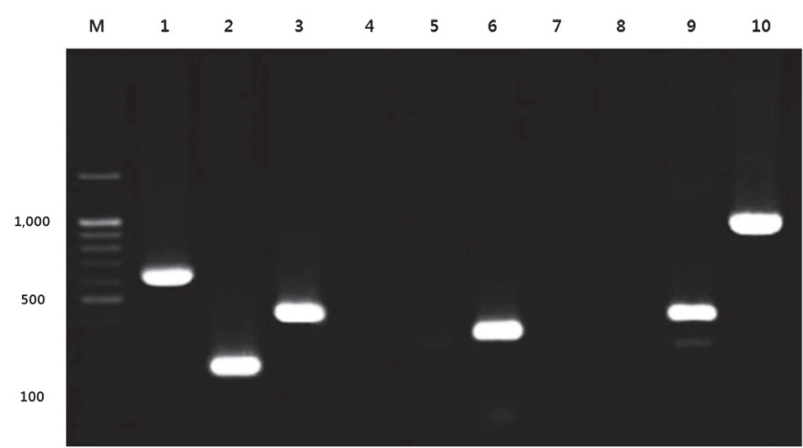

Fig. 2. Agarose gel (1.2\%) electrophoresis of PCR products obtained with specific primers for the cryl genes of $B$. thuringiensis subspecies kurstaki KB100. M: 100 bp ladder marker; lane 1: cry1Aa; lane 2: cry1Ab; lane 3: cry1Ac; lane 4: cry1B; lane 5: cry1C; lane 6: cry1D; lane 7: cry1E; lane 8: cry1F; lane 9: cry1G; lane 10: cry1I.

taki KB100 strain that was selected for the present study has cry $1 \mathrm{Aa}$, cry1Ab, cry1Ac, cry1D, cy1G, and cry1I genes (Fig. 2) and could be assumed to have high insecticidal activities in $S$. exigua because of cry1Aa, cry1Ab, and cry $1 \mathrm{D}$ genes. In particular, compared to the cry genes of the B. thuringiensis KB100 and HD-1 strains, which both showed high activity in $S$. exigua, the kurstaki KB100 strain had cry1Ab genes that were not identified in other strains.

\section{B. thuringiensis subsp. kurstaki KB100 strain: Western blotting analysis}

In the results from the western blotting method experiments, it was identified that the cry genes of the kurstaki KB100 strain showed 100\% insecticidal activity in $S$. exigua compared to the $B$. thuringiensis subspecies kurstaki HD-1 strain, which was the reference strain.

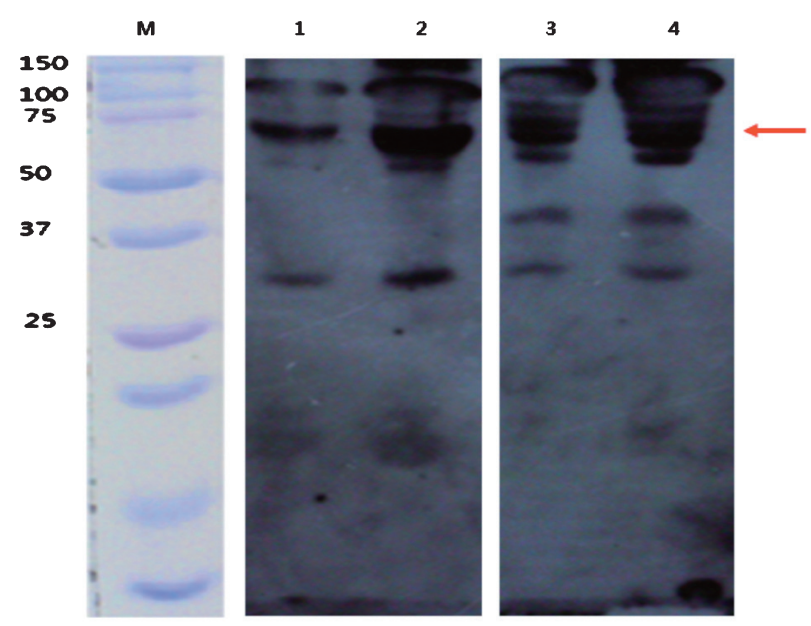

Fig. 3. Western blotting analysis of the B. thuringiensis subspecies kurstaki KB100 (Cry1Ab protein). M: standard marker; lane 1: B. thuringiensis subspecies kurstaki KB100 $(3 \mu \mathrm{l})$; lane 2: B. thuringiensis subspecies kurstaki KB100 (5 $\mu \mathrm{l})$; lane 3: B. thuringiensis subspecies kurstaki HD-1 (3 $\mu \mathrm{l})$; lane 4: B. thuringiensis subspecies kurstaki $\mathrm{HD}-1(5 \mu \mathrm{l})$
The existence of cry $1 \mathrm{Ab}$ proteins was checked using an antibody (anti-Bacillus thuringiensis, CRY1Ab toxin antibody (Ca.ab51586)) with the endotoxin proteins. According to results, $130 \mathrm{kDa}$ and $60 \mathrm{kDa}$ bands could be identified (Fig. 3). Because it is known that trypsin plays important roles in the decomposition of cry 1 proteins, according to Rukmini et al. (2000), the possibility for tannic acid to suppress the excessive decomposition of the cry 1 proteins of the B. thuringiensis KB100 strain by trypsin among $S$. exigua proteases could be predicted.

Identifying inhibition of trypsin, a $S$. exigua midgut digestive enzyme, by tannic acid

S. exigua's mid-gut proteases consist of serine proteases, such as trypsin, chymotrypsin, and elastase (Oppert, 1999). Using highly specific substrates to determine the characteristics of the digestive enzymes of insects is known to be useful (Law et al., 1977). S. exigua's mid-gut proteases were induced to react with specific substrates, and the activity of the proteases was measured. When the protease activity was measured using azocasein, which is a serine substrate, a value of $100 \%$ was indicated, and when BApNA and BPVApNA, which are trypsin substrates, were used, values of $91.4 \pm$ $1.8 \%$ and $89.4 \pm 0.7 \%$ were shown, respectively. BTpNA, SAAPPpNA, and AAVApNA were among the chymotrypsin substrates used, and the protease activity levels were shown to be $55.4 \pm 0.6 \%, 56.5 \pm 3.9 \%$, and $52.7 \pm$ $1.5 \%$, respectively. SAAApNA and SAAPLpNA were the elastase substrates used, and activity levels of $48.5 \pm$ $1.6 \%$ and $38.7 \pm 4.9 \%$ were shown, respectively. High protease activity levels, reaching approximately 90\%, were shown when measured using trypsin-specific substrates, while protease activity levels of approximately $55 \%$ were shown when chymotrypsin substrates were used. When elastase substrates were used, the activity levels were approximately 44\%, which were the lowest among those shown by the three types of proteases.

Based on these results, it could be assumed that among $S$. exigua's mid-gut proteases, trypsin exhibits the highest activity. To identify the degree of inhibition of proteolytic activity in $S$. exigua mid-gut proteasespecific substrate reaction tests, $S$. exigua mid-gut fluids were treated with tannic acid at four concentrations

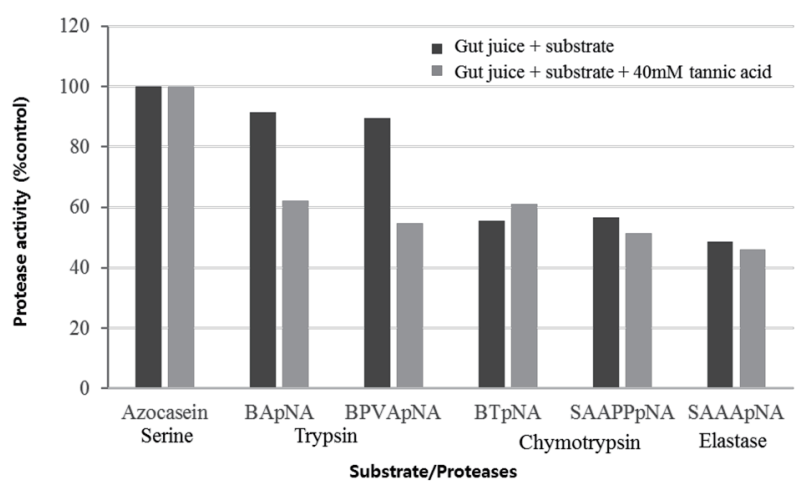

Fig. 4. Comparison of proteolytic activity when using $40 \mathrm{mM}$ of tannic acid with the substrates of the proteolytic enzyme. 
$(10,20,40$, and $80 \mathrm{mM})$, separately, and protease activity levels were measured. When $S$. exigua mid-gut fluid was treated with $40 \mathrm{mM}$ of tannic acid and the levels of protease activity on different substrates were measured, BApNA and BPVApNA, which are trypsin substrates, showed activity levels of $62.2 \pm 0.3 \%$ and $54.5 \pm 1.1 \%$, respectively, indicating that $40 \mathrm{mM}$ of tannic acid inhibited proteolytic activity on these substrates (Fig. 4). Unlike the results for trypsin, the extent to which tannic acid inhibited proteolytic activity on serine, chymotrypsin, and elastase substrates were insignificant. In comparison, the activity of trypsin in $S$. exigua mid-gut fluid on different substrates was suppressed by approximately $30-40 \%$ when treated with $40 \mathrm{mM}$ of tannic acid. Tannic acid could be expected to effectively inhibit the activity of trypsin among serine proteases.

\section{Analysis of the activity of trypsin among $S$. exigua mid-gut proteases and identification of the inhibi- tory activity of tannic acid}

A colorimetric analysis for trypsin activity was conducted to identify the inhibitory activity of tannic acid on the activity of trypsin among $S$. exigua proteases. For accurate analysis of trypsin activity, a standard curve was drawn using p-nitroaniline, which is a trypsin substrate (Fig. 5). The results of the analyses of untreated larvae,

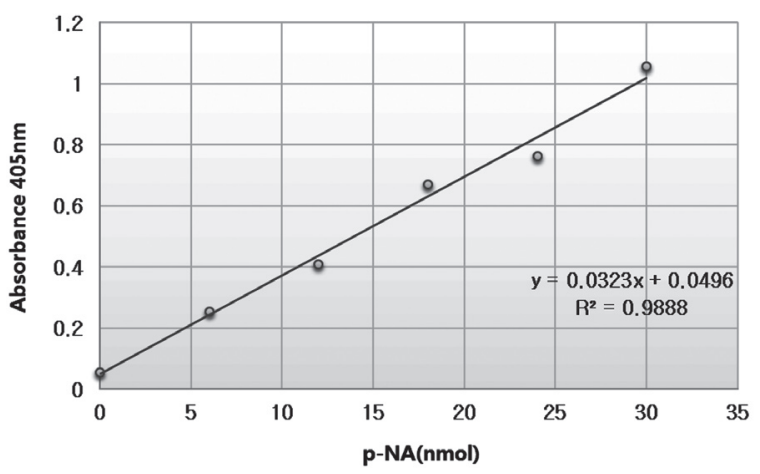

Fig. 5. The p-NA standard curve, performed according to the assay protocol.

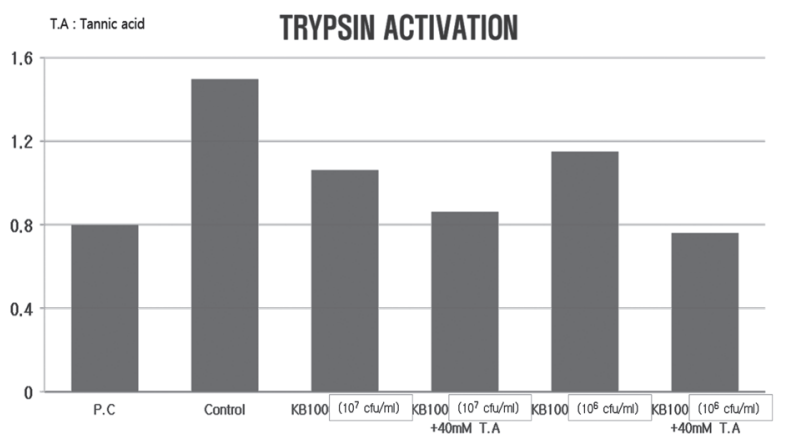

Fig. 6. Trypsin activity of the third larvae after being fed the $B$. thuringiensis KB100 single treatment and B. thuringiensis $\mathrm{KB} 100$ and $40 \mathrm{mM}$ of tannic acid feed. those larvae that died after eating the $B$. thuringiensis KB100 strain, and those larvae that died after eating the B. thuringiensis KB100 strain and $40 \mathrm{mM}$ of tannic acid are shown in Fig. 6. It was identified that trypsin activity slightly decreased in larvae that ate the B. thuringiensis KB100 strain and $40 \mathrm{mM}$ of tannic acid, compared to the positive control, the control, and those larvae that ate the $B$. thuringiensis KB100 strain $\left(1.05 \times 10^{7}, 1.05\right.$ $\times 10^{6}$ ). Similar to the results of SDS-PAGE, these results indicated that $40 \mathrm{mM}$ of tannic acid inhibits trypsin activity in $S$. exigua.

\section{S. exigua's trypsin gene sequencing and qRT-PCR analysis}

In the qRT-PCR analyses, differences in trypsin gene expression levels were identified in untreated larvae, those larvae that died after eating the $B$. thuringiensis KB100 strain, and those larvae that died after eating the B. thuringiensis KB100 strain and $40 \mathrm{mM}$ of tannic acid. The trypsin RNA sequence was identified by synthesizing and amplifying cDNA (Fig. 7). The partial sequence is indicated by $\mathrm{B}$, and the bands were identified through electrophoresis. The sequence of the actin RNA of $S$. exigua, which is a positive control, was identified in the Genbank (accession no. AY507963) and primers were made to identify the bands through electrophoresis (Fig.

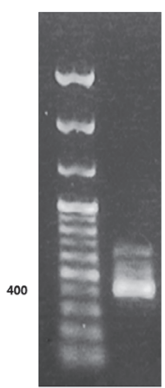

(A)
CCACCTTGGGGCAACAGCGGTGGTGCCGTTCACAACGTCG 40 CCCAGAACATCGTTCACGGTTCATACAACTCCAGAACTTTG 80 GACAACGACATCGCTATCCTCCGCTCCGCCTCCACCTTCAC 120 CTTCAACAACAATGTCCGCGCTGCCTCCGTTGCTGGTTCCA 160 ACTACTTCCCCGCTGACAACTCTGCCGCCTGGGCTGCCGG 200 ATGGGGAACCACCTCTTCTGGTGCTAGCTCCGGCTCCGAG 240 CAGCTCCGTCACGTGCAGCTGCAGATCATCAACCAGAACA 280 CTTGCAGAAACAACTACGCTACCCGTGGAATCACTATCACC 320 GACAACATGTTGTGCTCTGGCTGGCCCACCGGTGGTCGCG 360 ACCAGTGCCAGGGTGACTCTGGTGGTCCTCTCTACACAGG 400 GGCCATCG

408

(B)

Fig. 7. An electrophoresis pattern (A) of the partial sequence (B) of an $S$. exigua trypsin gene.

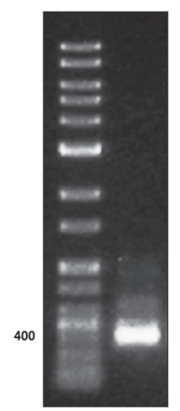

(A)
CCCAGAGCAAGAGAGGTATCCTCACCCTGAAGTACCCCAT 40 CGAGCACGGTATCATCACCAACTGGGATGACATGGAGAAG 80 ATCTGGCACACCTTCTACAACGAGCTGCGCGTCGCCCCTG 120 AGGAACACCCAGTCCTCCTGACTGAGGCTCCCCTCAACCC 160 TAAGGCCAACAGGGAGAAGATGACCCAGATCATGTTTGAG 200 ACCTTCAACTCCCCCGCCATGTACGTCGCCATCCAGGCCGT 240 GCTCTCTCTGTACGCCTCTGGTCGTACCGCCGGTATCGTCT 280 TGGACTCCGGTGATGGTGTCTCCCACACCGTCCCCATCTAC 320 GAAGGTTACGCCCTGCCCCACGCCATCCTCCGTCTGGACTT 360 GGCTGGTCGCGACTTGACCGACTACCTCATGAAGATCCTC 400 ACCGAGAGGGGTTACT

(B)

Fig. 8. An electrophoresis pattern (A) of the partial sequence (B) of an S. exigua actin (Genbank accession no. AY507963) gene. 
Table 3. Mean cycle threshold (Ct) values of qRT-PCR for trypsin and actin genes

\begin{tabular}{|c|c|c|c|c|c|c|}
\hline \multirow{2}{*}{ Pest } & \multirow{2}{*}{$\begin{array}{l}\text { Target } \\
\text { gene }\end{array}$} & \multirow{2}{*}{$\begin{array}{c}\text { Target } \\
\text { sample }\end{array}$} & \multicolumn{3}{|c|}{ Revelation value (Ct value) } & \multirow{2}{*}{$\begin{array}{c}\text { Average } \\
\text { (Mean } \pm \text { SD) }\end{array}$} \\
\hline & & & Rep. 1 & Rep. 2 & Rep. 3 & \\
\hline \multirow{9}{*}{ S. exigua } & \multirow{3}{*}{ Trypsin 1} & KB100 & 35.12 & 34.8 & 34.93 & $34.95 \pm 0.83$ \\
\hline & & $\mathrm{KB} 100+\mathrm{T} \cdot \mathrm{A}$ & 32.53 & 32.73 & 32.15 & $32.47 \pm 0.32$ \\
\hline & & Non & 30.52 & 30.07 & 30.25 & $30.28 \pm 0.24$ \\
\hline & \multirow{3}{*}{ Trypsin 2} & KB100 & 30.48 & 30.52 & 30.23 & $30.41 \pm 0.18$ \\
\hline & & $\mathrm{KB} 100+\mathrm{T} \cdot \mathrm{A}$ & 28.53 & 27.25 & 28.12 & $27.96 \pm 0.84$ \\
\hline & & Non & 25.45 & 25.85 & 25.23 & $25.51 \pm 0.34$ \\
\hline & \multirow{3}{*}{ Actin } & KB100 & 22.56 & 22.53 & 23.12 & $22.73 \pm 0.39$ \\
\hline & & $\mathrm{KB} 100+\mathrm{T} . \mathrm{A}$ & 22.72 & 22.11 & 22.17 & $22.33 \pm 0.39$ \\
\hline & & Non & 22.89 & 22.63 & 22.73 & $22.75 \pm 0.14$ \\
\hline
\end{tabular}

Values represent by mean $\pm \mathrm{SD}, *: P<0.05$; **: $P<0.01$; Completely randomized one-way analysis of variance,

ANOVA, Post Hoc Test by Duncan in SPSS version 18.0 NS; statistically not significant.

8). The results of the qRT-PCR indicated that the expression level of the trypsin 1 gene was lower when the larvae were fed the $B$. thuringiensis KB100 strain and $40 \mathrm{mM}$ of tannic acid, compared to larvae fed only the B. thuringiensis KB100 strain. Likewise, the expression level of the trypsin 2 gene was also lower when the larvae were fed the $B$. thuringiensis KB100 strain and $40 \mathrm{mM}$ of tannic acid (Table 3 ). The expression level of actin, which is a housekeeping gene, was not significantly different among the untreated larvae, those larvae that died after eating the $B$. thuringiensis KB100 strain, and those larvae that died after eating the B. thuringiensis KB100 strain and $40 \mathrm{mM}$ of tannic acid.

\section{Immunofluorescence and confocal laser-scanning microscopy}

Immunofluorescence experiments were conducted to detect trypsin, which is a target protein of $S$. exigua proteases. The detected amounts and images of trypsin were analyzed under an immunofluorescence microplate reader and a confocal laser-scanning microscope, using antibodies bound to fluorophores. Fluorophores absorb light with certain wavelengths and show colors according to the wavelength range. Fluorescein-labelled antibodies that are specifically bound to trypsin existing in S. exigua were induced to react with the trypsin, and the detected amounts of trypsin were measured. The amount of trypsin detected from untreated larvae was approxi-

Table 4. Revelation value of immunofluorescence of trypsin (D-1): sc-137077 and mouse IgG2a antibody after a 30 minute feeding

\begin{tabular}{cc}
\hline Treatment & $\begin{array}{c}\text { Revelation value } \\
\text { (Average) }\end{array}$ \\
\hline $\begin{array}{c}\text { Fluorescein-labeled antibody } \\
\text { Fluorescein-labeled antibody } \\
+40 \text { mM tannic acid }\end{array}$ & $3,505 \pm 155$ \\
None & $15,959 \pm 580$ \\
\hline
\end{tabular}

mately 3,505 amol, and the amount of trypsin detected from the larvae treated with fluorescein-labelled antibodies was approximately 15,959 amol. The amount of trypsin detected from the larvae treated with $40 \mathrm{mM}$ of tannic acid was approximately 11,754 amol (Table 4). After identifying the detected amounts of trypsin in numerical values, the images were identified using a confocal laser scanning microscope (Fig. 9). Trypsin activity was identified in the gut of the insect using fluores-

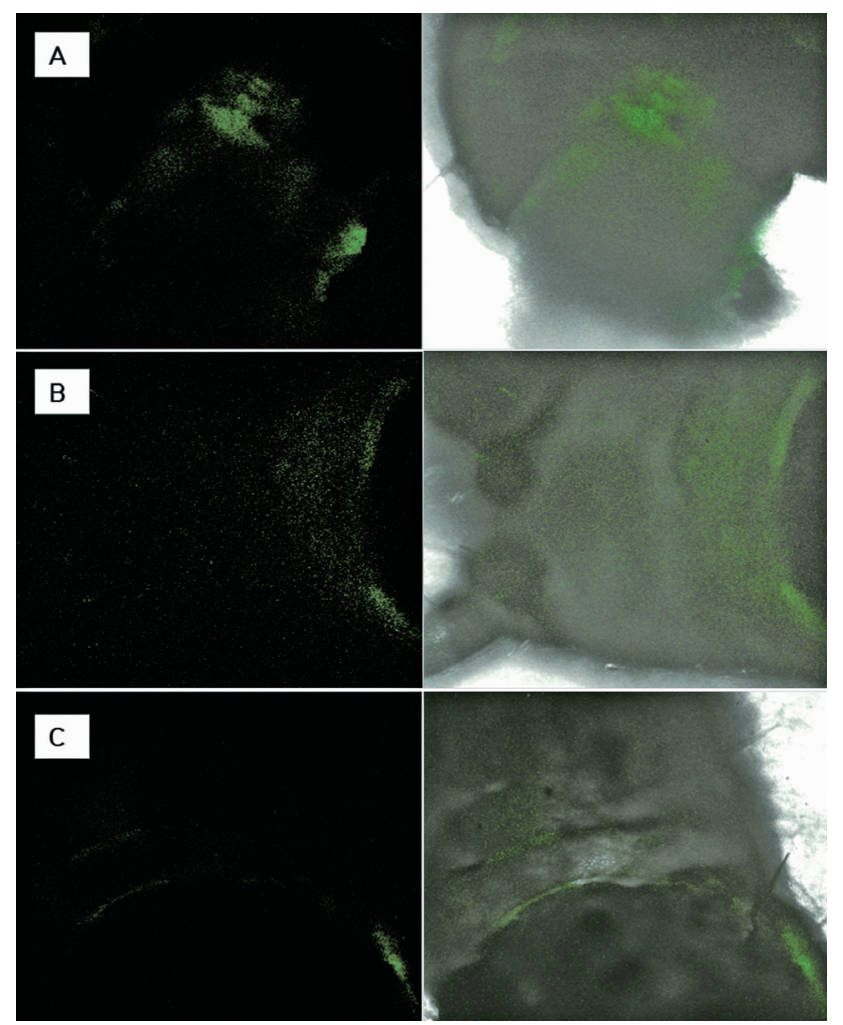

Fig. 9. Immunofluorescence and microscopic imaging (Carl Zeiss Axiovert, 135 M microscope) of Trypsin (D-1): sc-137077 and a mouse IgG2a antibody after a 30 minute feeding; (A) and (B): Antibody treatment; (C): Antibody and $40 \mathrm{mM}$ of tannic acid. 
cence (Fig. 9A, B), and when the larvae were treated with $40 \mathrm{mM}$ of tannic acid, trypsin activity decreased (Fig. 9C). Trypsin activity was shown to be lower following the treatment with tannic acid, which is a protease inhibitor.

Diverse attempts to increase the insecticidal activity of B. thuringiensis have been made. Heimpel (1967) reported that when the use of 35 types of agricultural chemicals in combination with $B$. thuringiensis was tested, insecticidal activity increased in six types of agricultural chemicals. These results have been seen not only with insecticides but also with many other compounds used to increase the insecticidal activity of B. thuringiensis. Salama et al. (1984) examined the addition of inorganic compounds or organic compounds to $B$. thuringiensis and evaluated the insecticidal activities of the mixtures on $S$. littoralis. They mixed $B$. thuringiensis with compounds using three methods: (i) they added compounds, such as sodium carbonate $\left(\mathrm{Na}_{2} \mathrm{CO}_{3}\right)$ and calcium carbonate $\left(\mathrm{CaCO}_{3}\right)$ to $B$. thuringiensis to enhance the alkalinity of insects' mid-guts to accelerate the dissolution of crystals, (ii) they added compounds, such as calcium chloride $\left(\mathrm{CaCl}_{2}\right)$ and magnesium chloride $\left(\mathrm{MgCl}_{2}\right)$, to $B$. thuringiensis to increase concentrations of $\mathrm{Ca}^{++}$ ions and $\mathrm{Mg}^{++}$ions to accelerate conversion of $B$. thuringiensis pre-toxins into active toxin, and (iii) they added compounds, such as borax and tannic acid, to $B$. thuringiensis to increase the activity of $B$. thuringiensis in insects. According to the experimental results, the B. thuringiensis subspecies entmocidus HD-635 combined with calcium carbonate remarkably increased activity on $S$. littoralis. The synergistic effects of the addition of calcium chloride and magnesium chloride were directly proportional to the concentrations of the added calcium chloride and magnesium chloride, and the $B$. thuringiensis added with borax and tannic acid also showed remarkable increases in insecticidal activity (Salama et al., 1984).

In a previous study by the current researchers, a new $B$. thuringiensis strain was isolated and identified, tannic acid was selected and mixed with the B. thuringiensis strain to increase its insecticidal activity to show synergistic effects, and diverse experiments were conducted to determine the causes of the results. According to the results of a colorimetric assay of trypsin activity, activity decreased slightly in larvae that ate the $B$. thuringiensis KB100 strain and $40 \mathrm{mM}$ of tannic acid. A trypsin gene expression level analysis conducted using qRT-PCR analysis and immunofluorescence antibody method experiments revealed that the $B$. thuringiensis KB100 strain was decomposed by $S$. exigua mid-gut proteases and that the addition of $40 \mathrm{mM}$ of tannic acid changed expression levels and the image analysis.

Trypsin is composed of three substances: cationic trypsinogen, anionic trypsinogen, and chymotrypsinogen and is decomposed by enterokinase into trypsin 1,2, and 3. According to Rukmini et al. (2000), cry1A (a), cry1A (b), and cry1A (c) proteins are quickly decomposed by trypsin. Trypsin decomposition of the cry toxins of the B. thuringiensis subspecies kurstaki LB1 and kurstaki HD251 was checked, and the results indicated that there

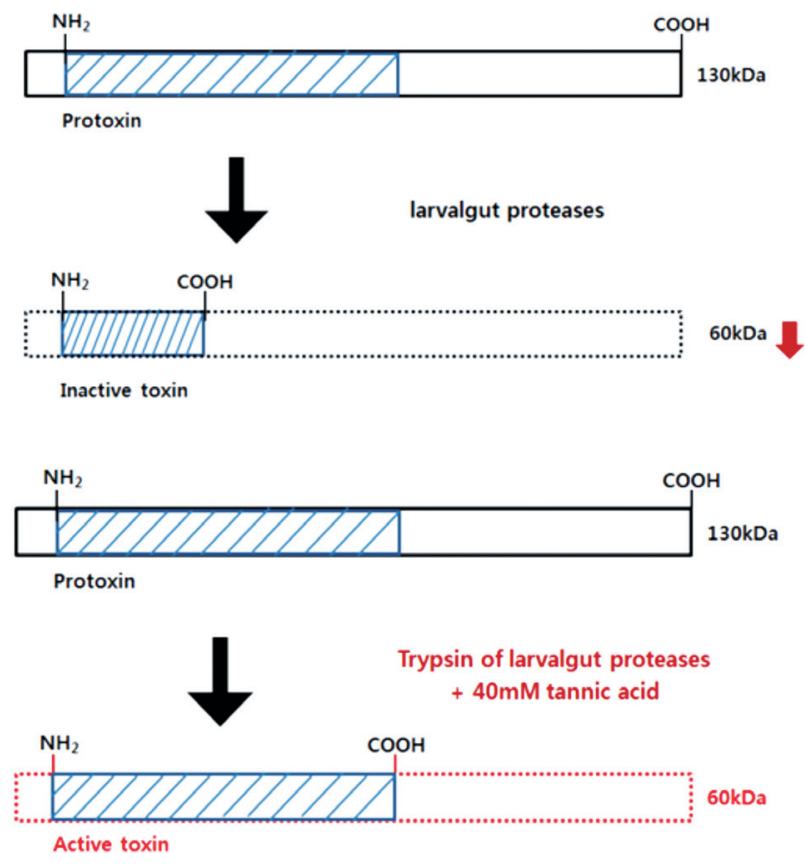

Fig. 10. The role of tannic acid in mid-gut trypsin (diagram of $S$ exigua).

were differences in digestion time (Rukmini et al., 2000). It could be assumed that in the case of the kurstaki KB100 strain, tannic acid effectively suppresses the activity of cry $1 \mathrm{Aa}$, cry $1 \mathrm{Ab}$, and cry $1 \mathrm{Ac}$ proteins when these proteins are hydrolyzed by trypsin (Fig. 10).

Therefore, for environmentally friendly control of $S$. exigua, which is an intractable pest, tannic acid added to $B$. thuringiensis products exhibits high activity, and the mechanism through which tannic acid effectively suppresses trypsin among diverse protease inhibitors can be identified. Future studies that attempt to enhance the toxicity of existing components with insecticidal activities of biological pesticides to control intractable pests should be conducted. The present study showed that the effects of microbial pesticides can be enhanced by appropriate improvement of formulations to relieve problems, such as narrow host ranges and low activity, which are disadvantages of biological pesticides. Research and development are necessary to enhance the effects of diverse methods for control of domestic intractable pests.

\section{ACKNOWLEDGEMENTS}

The present study is based on the results of the study "Control of moths using insect pathogenic bacteria" (Project No. PJ010029) and was supported by the Rural Development Administration. We extend our thanks for the support.

\section{REFERENCES}

Abdullah, M. A. F., S. Moussa, M. D. Taylor and M. J. Adang 2009 Manduca sexta (Lepidoptera: Sphingidae) cadherin fragments function as synergists for Cry1A and Cry1C Bacillus thuring- 
iensis toxins against noctuid moths Helicoverpa zea, Agrotis ipsilon, and Spodoptera exigua. J. Pest. Sci., 65: 1097-1103

Bradford, M. M. 1976 A rapid and sensitive method for the quantitation of microgram quantities of protein utilizing the principle of protein-dye binding. Anal. Biochem., 72: 248-254

Bravo, A., S. Sarabia, L. Lopez, H. Ontiveros, C. Abarca, A. Ortiz, M. Ortiz, L. Lina, F. J. Villalobos and G. Peña 1998 Characterization of cry genes in a Mexican Bacillus thuringiensis strain collection. Appl. Environ. Microbiol., 64: 49654972

Chan, B. G., A. Waiss and M. Lukefahr 1978 Condensed tannin, an antibiotic chemical from Gossypium hirsutum. J. Insect Physiol., 24: 113-118

de Maagd, R. A., A. Bravo, C. Berry, N. Crickmore and H. E. Schnepf 2003 Structure, diversity, and evolution of protein toxins from spore-forming entomopathogenic bacteria. Annu. Rev. Genet., 37: 409-433

Donovan, W. P., Y. Tan, C. S. Jany and J. M. Gonzalez Jr 1994 U.S. Patent No. 5, 322, 687. Washington, DC: U.S. Patent and Trademark Office

Eveleens, K., R. Van Den Bosch and L. Ehler 1973 Secondary outbreak induction of beet armyworm by experimental insecticide applications in cotton in California. Environ. Entomol., 2: 497-504

Forcada, C., E. Alcacer, M. D. Garcerá and R. Martinez 1996 Differences in the midgut proteolytic activity of two Heliothis virescens strains, one susceptible and one resistant to Bacillus thuringiensis toxins. Arch. Insect Biochem. Physiol., 31: 257-272

Goh, H., S. Lee, B. Lee, K. Choi and J. Kim 1990 Simple mass rearing of beet armyworm Spodoptera exigua (Hübner) (Lepidoptera: Noctuidae), on an artificial diet. Korean $J$. Appl. Entomol., 29: 180-183

Goh, H., J. Park, Y. Choi, K. Choi and I. Park 1991 The host plants of beet armyworm, Spodoptera exigua (Hübner), (Lepidoptera: Noctuidae), and its occurrence. Korean J. Appl. Entomol., 30: 111-116

Heimpel, A. M. 1967 A critical review of Bacillus thuringiensis var. thuringiensis Berliner and other crystalliferous bacteria. Annu. Rev. Entomol., 12: 287-322

Hernández, C. S. and J. Ferré 2005 Common receptor for Bacillus thuringiensis toxins Cry $1 \mathrm{Ac}, \mathrm{Cry} 1 \mathrm{Fa}$, and Cry1Ja in Helicoverpa armigera, Helicoverpa zea, and Spodoptera exigua. Appl. Environ. Microbiol., 71: 5627-5629

Isabel, G., S. Jorge, M.-G. Carlos, M. Violeta, S. G. Sarjeet, S. Mario and B. Alejandra 2014 Bacillus thuringiensis Cry1A toxins are versatile proteins with multiple modes of action: two distinct pre-pores are involved in toxicity. Biochem. J., 459: 383-396

Jin, N. Y., S. Y. Jung, C. Park, S. K. Paek, M. J. Seo, Y. N. Youn and Y. M. Yu 2009 The synergy effects of mixed treatment with tannic acid and Bacillus thuringiensis subsp. kurstaki KB100 against Spodoptera exigua (Lepidoptera: Noctuidae). Korean J. Appl. Entomol., 48: 519-526

Jin, N. Y., Y. K. Lee, B. R. Lee, Y. S. Kim, J. H. Jun, M. J. Seo, Y. N. Youn, C. Yasunaga-Aoki and Y. M. Yu 2015 Tannic acid enhancing insecticidal activity of protoxin produced in Bacillus thuringiensis subsp. kurstaki KB100 strain against Spodoptera exigua. J. Fac. Agr. Kyushu Univ., 60: 97-102

Jongsma, M. A., J. Peters, W. J. Stiekema and D. Bosch 1996 Characterization and partial purification of gut proteinases of Spodoptera exigua Hübner (Lepidoptera: Noctuidae). Insect Biochem. Mol. Biol., 26: 185-193

Jung, C. R., Y. J. Park and K. S. Boo 2003 Optimal sex pheromone composition for monitoring Spodoptera exigua (Lepidoptera: Noctuidae) in Korea. J. Asia Pac. Entomol., 6: 175-182

Jung, S. Y., M. J. Seo, Y. N. Youn and Y. M. Yu 2010 Characteristics of $\delta$-Endotoxin protein produced from Bacillus thuringiensis subsp. kurstaki KB099 isolate showing high bioactivity against Spodoptera litura. Korean J. Pestic. Sci., 14: 446-455

Kaminska, P., S. A. Yernazarova, E. Murawska, J. Swiecicki, K. Fiedoruk, D. K. Bideshi and I. Swiecicka 2014 Comparative analysis of quantitative reverse transcription real-time PCR and commercial enzyme immunoassays for detection of enterotoxigenic Bacillus thuringiensis isolates. FEMS Microbiol. Lett., 357: 34-39

Kim, S. G., S. S. Kim, I. C. Hwang, J. D. Park, D. I. Kim and H. G. Choi 2004 Effects of different temperatures on the pathogenicity of Spodoptera exigua nucleopolyhedrovirus (SeNPV). Korean J. Appl. Entomol., 43: 329-332

Law, J. H., P. E. Dunn and K. Kramer 1977 Insect proteases and peptidases. Adv. Enzymol. Relat. Areas Mol. Biol., 45: 389425

Lee, I., Y. Je, J. Chang, J. Roh, H. Oh, S. Lee, S. Shin and K. Boo 2001 Isolation and characterization of a Bacillus thuringiensis ssp. kurstaki strain toxic to Spodoptera exigua and Culex pipiens. Curr. Microbiol., 43: 284-287

Lord, J. C. and A. H. Undeen 1990 Inhibition of the Bacillus thuringiensis var. israelensis toxin by dissolved tannins. Environ. Entomol., 19: 1547-1551

Luo, K., D. Banks and M. J. Adang 1999 Toxicity, binding, and permeability analyses of four Bacillus thuringiensis cryl $\delta$-endotoxins using brush border membrane vesicles of Spodoptera exigua and Spodoptera frugiperda. Appl. Environ. Microbiol., 65: 457-464

Maclntosh, S. C., G. M. Kishore, F. J. Perlak, P. G. Marrone, T. B Stone, S. R. Sims and R. L. Fuchs 1990 Potentiation of Bacillus thuringiensis insecticidal activity by serine protease inhibitors. J. Agric. Food Chem., 38: 1145-1152

Meinke, L. J. and G. W. Ware 1978 Tolerance of three beet armyworm strains in Arizona to methomyl. J. Econ. Entomol., $\mathbf{7 1}$ 645-646

Minamikawa, H. 1937 Survey on the tobacco cutworm, Spodoptera litura Fabricius Taiwan Central Res. Ins. Agr. Report., 70: 1-66

Mochida, O. and T. Okada 1974 A bibliography of Spodoptera spp. (Lepidoptera: Noctuidae). Miscellaneous Bulletin Kyushu National Agricultural Experiment Station.

Navon, A., J. Hare and B. Federici 1993 Interactions among Heliothis virescens larvae, cotton condensed tannin and the CryIA (c) $\delta$-endotoxin of Bacillus thuringiensis. J. Chem. Ecol., 19: 2485-2499

Oppert, B. 1999 Protease interactions with Bacillus thuringiensis insecticidal toxins. Arch. Insect Biochem. Physiol., 42 $1-12$

Pfaffl, M. W. 2001 A new mathematical model for relative quantification in real-time RT-PCR. Nucleic Acids Res., 29: e45-e45

Porcar, M., C. Martínez and P. Caballero 2000 Host range and gene contents of Bacillus thuringiensis strains toxic towards Spodoptera exigua. Entomol. Exp. Appl., 97: 339-346

Raymond, B., P. R. Johnston, C. Nielsen-LeRoux, D. Lereclus and N. Crickmore 2010 Bacillus thuringiensis: an impotent pathogen? Trends Microbiol., 18: 189-194

Rhoades, D. F. and R. G. Cates 1976 Toward a general theory of plant anti-herbivore chemistry. In "Biochemical interaction between plants and insects", ed. by J. Wallace, Springer, pp. 168-213

Ruiz, L. M., C. Segura, J. Trujillo and S. Orduz 2004 In vivo binding of the cry $11 \mathrm{Bb}$ toxin of Bacillus thuringiensis subsp. medellin to the midgut of mosquito larvae (Diptera: Culicidae). Memórias do Instituto Oswaldo Cruz, 99: 73-79

Rukmini, V., C. Y. Reddy and G. Venkateswerlu 2000 Bacillus thuringiensis crystal $\delta$-endotoxin: role of proteases in the conversion of protoxin to toxin. Biochimie., 82: 109-116

Salama, H., M. Foda and A. Sharaby 1984 Novel biochemical avenues for enhancing Bacillus thuringiensis endotoxin potency against Spodoptera littoralis [Lep.: Noctuidae]. Entomophaga., 29: 171-178

Sanchis, V., D. Lereclus, G. Menou, J. Chaufaux, S. Guo and M. M. Lecadet 1989 Nucleotide sequence and analysis of the N-terminal coding region of the Spodoptera-active $\delta$-endotoxin gene of Bacillus thuringiensis aizawai 7.29 Mol. Microbiol., 3: 229-238

Schnepf, E., N. Crickmore, J. Van Rie, D. Lereclus, J. Baum, J. Feitelson, D. Zeigler and D. Dean 1998 Bacillus thuringien- 
sis and its pesticidal crystal proteins. Microbiol. Mol. Biol. Rev., 62: 775-806

Tamez-Guerra, P., M. M. Iracheta, B. Pereyra-Alférez, L. J. GalánWong, R. Gomez-Flores, R. S. Tamez-Guerra and C. RodriguezPadilla 2004 Characterization of Mexican Bacillus thuringiensis strains toxic for lepidopteran and coleopteran larvae. J. Invertebr. Pathol., 86: 7-18

Tojo, A. and K. Aizawa 1983 Dissolution and degradation of Bacillus thuringiensis $\delta$-endotoxin by gut juice protease of the silkworm Bombyx mori. J. Invertebr. Pathol., 45: 576580

Visser, B., E. Munsterman, A. Stoker and W. G. Dirkse 1990 A novel Bacillus thuringiensis gene encoding a Spodoptera exigua-specific crystal protein. J. Bacteriol., 172: 6783-6788

Visser, B., T. van der Salm, W. van den Brink and G. Folkers 1988 Genes from Bacillus thuringiensis entomocidus 60.5 coding for insect-specific crystal proteins. Mol. Gen. Genet., 212: 219-224

Xue, J., G. Liang, N. Crickmore, H. Li, K. He, F. Song and J. Zhang
2008 Cloning and characterization of a novel cry1A toxin from Bacillus thuringiensis with high toxicity to the Asian corn borer and other Lepidopteran insects. FEMS Microbiol. Lett., 280: 95-101

Yang, Z., H. Chen, W. Tang, H. Hua and Y. Lin 2011 Development and characterization of transgenic rice expressing two Bacillus thuringiensis genes. Pest Manag. Sci., 67: 414-422

Ye, R., H. Huang, Z. Yang, T. Chen, L. Liu, X. Li and Y. Lin 2009 Development of insect-resistant transgenic rice with cry $1 \mathrm{C}^{*}$ free endosperm. Pest Manag. Sci., 65: 1015-1020

Yoo, J. K., J. O. Lee and I. H. Choi 1995 Investigation of the control probability on beet armyworm, Spodoptera exigua, using a synthetic sex pheromone in a Welsh onion field. $R D A J$. Agric. Sci., 37: 334-339

Zhu, Y. C., C. Abel and M. S. Chen 2007 Interaction of cry1Ac toxin (Bacillus thuringiensis) and proteinase inhibitors on the growth, development, and midgut proteinase activities of the bollworm, Helicoverpa zea. Pestic. Biochem. Physiol., 87: $39-46$ 